\title{
Kemampuan Menyimak Anak Melalui Kegiatan Bercerita (Studi Kasus Pada Taman Penitipan Anak Athirah Makassar)
}

\section{Children's Listening Ability Through Storytelling Activities (Case Study at Athirah Child Care Park Makassar)}

\author{
Hasmawaty ${ }^{1 *}$ \\ 1) Universitas Megaresky Makassar, Prodi Pendidikan Guru Sekolah Dasar \\ "Penulis Korespondensi: hasmawaty567@gmail.com
}

Received: 2804 2020/ Resived: 2005 2020/ Accepted: 13062020

\begin{abstract}
Abstrak
Penelitian ini adalah penelitian kualitatif dengan pendekatan studi kasus. Instruksi penelitian adalah peneliti itu sendiri. Pengumpulan data menggunakan metode observasi, wawancara, dokumentasi, dan rekaman. Responden adalah tiga anak dengan rentang usia 2 hingga 5 tahun dan dua tutor. Hasil penelitian menunjukkan bahwa (1) Kedua tutor menggunakan teknik yang berbeda dalam melaksanakan kegiatan bercerita. Tutor A menggunakan pendekatan Contextual Teaching and Learing (CTL) dengan melibatkan anak-anak dalam memilih cerita, sementara tutor B menggunakan pendekatan konvensional (guru berpusat). Isi cerita disesuaikan dengan pengalaman anak-anak dari kehidupan sehari-hari mereka untuk perkembangan emosi, perkembangan sosial, dan perkembangan spiritual mereka, (2) Setiap anak memiliki pemahaman mendengarkan yang baik. Anak-anak dapat menjawab pertanyaan guru mengenai judul dan aktor dalam cerita, memahami cerita dan menceritakannya kembali dengan kata-kata mereka sendiri. Pemahaman mendengarkan anak-anak dapat dilihat sebagai berikut; ketika A (tutor) membawakan cerita, setiap anak diberi kesempatan yang sama untuk menjawab pertanyaan dan menceritakan kembali cerita, di sisi lain, $B$ (tutor) hanya memberikan kesempatan kepada beberapa anak atau satu anak. (3) Faktor penghambat dan pendukung pada pemahaman mendengarkan anak-anak pada awalnya dari tutor sebagai pendongeng, aspek cerita, anak-anak sebagai pendengar, dan situasi belajar.
\end{abstract}

Kata-kata Kunci: Kemampuan Menyimak, Metode Bercerita, Pendidikan Anak Usia Dini.

\begin{abstract}
This study is a qualitative research with a case study approach. The instrment of the research was the researcher herself. The data collection employed observation, interview, documentation, and recording methods. The respondents were three children with the age range 2 to 5 years old and two tutors. The result of the research
\end{abstract}


indicates that (1) The two tutors used different techniques in implementing the story telling activity. Tutor A employed Contextual Teaching and Learing (CTL) approach by involving children in choosing the stories, while tutor B employed conventional approach (teacher centered). The content of the story was adjusted according to children's experience on from their daily lives for their emotional development, social development, and spiritual development, (2) Each child has good listening comprehension. Children were able to answer teacher's questions conserning the title and the actor in the story, comprehend the story and retell it with their own words. The children's listening comprehension could be seen as follows; when A (the tutor) conducted the story, each child was given the same opportunity to answer the questions and retell the story, on the other hand, B (the tutor) merely gave opportunity to several children or one child. (3) The inhibiting and the supporting factors on children's listenig comprehension were initially from the tutor as a story teller, the aspect of the story, the childrens as the listener, and the learning situation.

Keywords: Listening Ability, Story Telling Method, Early Childhood Education,

\section{PENDAHULUAN}

Anggapan bahwa pendidikan baru bisa dimulai setelah usia sekolah dasar yaitu usia tujuh tahun ternyata tidaklah benar. Bahkan pendidikan yang dimulai pada usia TK (4-6 tahun) pun sebenarnya sudah terlambat. Hasil penelitian di bidang neurologi yang dilakukan Benyamin S. Bloom, seorang ahli pendidikan dari Universitas Chicago, Amerika Serikat mengemukakan bahwa pertumbuhan sel jaringan otak pada anak usia 0-4 tahun mencapai 50 persen hingga usia 8 tahun mencapai 80 persen. Artinya bila pada usia tersebut otak anak tidak mendapatkan rangsangan yang maksimal maka otak anak tidak akan berkembang secara optimal. Pada dasawarsa kedua yaitu usia 18 tahun perkembangan jaringan otak telah mencapai 100 persen. Oleh sebab itu masa kanak-kanak dari usia 0-8 tahun disebut masa emas (Golden Age) yang hanya terjadi satu kali dalam perkembangan kehidupan manusia sehingga sangatlah penting untuk merangsang pertumbuhan otak anak dengan memberikan perhatian terhadap kesehatan anak, penyediaan gizi yang cukup, dan pelayanan pendidikan (Diktentis, 2003, p. 1). Layanan pendidikan kepada anak usia dini merupakan dasar yang sangat berpengaruh terhadap perkembangan anak selanjutnya hingga dewasa. Hal ini diperkuat oleh Hurlock bahwa tahun-tahun awal kehidupan anak merupakan dasar yang cenderung bertahan dan mempengaruhi sikap dan perilaku anak sepanjang hidupnya (Hurlock, 1991, p. 27 dalam Priyanto, 2014, p. 41).

Dalam pembelajaran di Taman Penitipan perlu diperhatikan beberapa aspek perkembangan pada anak. Salah satu di antaranya adalah aspek perkembangan 
bahasa anak. Bahasa merupakan medium yang paling penting dalam komunikasi manusia. Bahasa bersifat unik sekaligus bersifat universal bagi manusia. Dalam kenyataan kegiatan sehari-hari kita amati pula bahwa hanya manusialah yang mampu menggunakan komunikasi verbal dan kita amati pula bahwa manusia mampu mempelajarinya. Inilah yang menyebabkan tingkah laku manusia secara esensial berbeda dengan tingkah laku binatang. Tingkah laku bahasa adalah satu di antara bentuk yang paling memberi ciri pada tingkah laku insani. Tingkah laku insani ini tergambar dari suasana adanya pengiriman dan penerima. Pengirim bisa dalam bentuk pembicara atau penulis, sedangkan penerima bisa dalam bentuk pendengar atau pembaca. Jadi keterampilan yang dimiliki anak mencakup empat keterampilan berbahasa, yaitu menyimak/mendengarkan, berbicara, menulis dan membaca. Keterampilan berbahasa tidak dikuasai dengan sendirinya oleh anak. Akan tetapi keterampilan berbahasa akan diperoleh melalui proses pembelajaran atau memerlukan upaya pengembangan. Pengembangan kemampuan bahasa lisan terkait pada lingkungan dimana anak tinggal. Lingkungan yang banyak memberikan stimulasi akan memperkaya perbendaharaan kata anak. Oleh sebab itu, diharapkan baik orang tua di lingkungan keluarga maupun guru di lingkungan sekolah agar dapat memberikan stimulasi pada anak agar kemampuan bahasa lisannya terutama kemampuan menyimak dapat berkembang secara optimal.

Pengembangan keterampilan menyimak pada anak berkaitan erat satu sama lain dengan keterampilan berbahasa khususnya berbicara. Anak yang berkembang keterampilan menyimaknya, akan berpengaruh terhadap perkembangan keterampilan berbicaranya. Menurut Tarigan tulisan Nurbiana Dhieni kedua keterampilan berbahasa tersebut merupakan kegiatan komunikasi dua arah yang bersifat langsung dan dapat merupakan komunikasi yang bersifat tatap muka (Dhieni, 2007, p. 4.6 dalam Rupina, Purwanthi, Yuline, 2016, p. 2).

Mendongeng atau bercerita merupakan cara terbaik bagi orang tua untuk mengkomunikasikan pesan-pesan cerita yang mengandung unsur etika, moral maupun nilai-nilai agama. Selain dapat bermanfaat untuk pengembangan kepribadian, akhlak maupun moral anak, bercerita dapat juga bermanfaat untuk meningkatkan pengembangan bahasa anak. Sejak dini anak memperoleh berbagai wawasan cerita yang memperkaya dan meningkatkan kemampuan kognitif, memori, imajinasi dan kreativitas bahasa. Menurut Clarke Stewart, bahwa orang tua yang sering bercerita akan menumbuhkan fantasi dan kreativitas bahasa pada anak-anak. Anak-anak sudah terlatih untuk menerima rangsangan luar yang dapat meningkatkan daya imajinasi, fantasi dan kreativitas untuk bercerita (Clarke Stewart, 1998 dalam Syarifuddin, 2010). Mengingat kemampuan menyimak merupakan dasar bagi seorang anak untuk dapat berbicara dengan baik maka diperlukan metode pengajaran yang sesuai dan menarik bagi anak. Salah satu metode yang diterapkan bagi pendidikan anak usia dini termasuk pada Taman Penitipan Anak adalah metode bercerita. Kegiatan ini sangat disukai anak, karena selain mengasyikkan juga banyak manfaatnya. Melalui bercerita guru dapat menyampaikan misi pembelajaran pada 
anak didik tanpa dirasakan menggurui. Dengan bercerita ada banyak hal yang didapat pada saat anak mendengarkan cerita ataupun setelah mendengarkan cerita bahkan ketika anak bercerita sendiri maupun saat ia menceritakan pengalamannya.

Kegiatan bercerita banyak diterapkan dalam pendidikan anak usia dini termasuk Taman Penitipan Anak Athirah sebagai lembaga PAUD jalur non formal. Kegiatan bercerita ini dilakukan hampir setiap hari. Selain dilaksanakan pada kegiatan inti dalam pembelajaran, guru juga menerapkannya sebagai kegiatan pembuka atau penutup. Selain itu guru memperdengarkan cerita kepada anak sebagai pengantar tidur siang. Kegiatan bercerita pada Taman Penitipan Anak Athirah ditunjang dengan ketersediaan sarana dan fasilitas penunjang kegiatan belajar misalnya, buku-buku cerita, buku cerita berseri, gambar, papan flannel, dan alat peraga lainnya. Melalui kegiatan bercerita ini anak diharapkan dapat mendengarkan secara aktif dan kreatif untuk memperoleh informasi, menangkap isi atau pesan serta memahami makna komunikasi yang disampaikan secara lisan.

Berdasarkan hasil penelitian yang dilakukan oleh Noviana, seorang guru perlu menggunakan metode bercerita yang relevan dan sesuai dengan kebutuhan anak yang dididik dengan tujuan untuk membantu anak yang mengalami permasalahan dalam belajar mendapatkan hasil belajar yang memuaskan (Noviana, 2013). Menurut Rahmat, kemampuan menyimak anak sebelum dan sesudah pemberian perlakuan atau metode cerita mengalami perbedaan yang signifikan. Dengan perbedaan tersebut dapat disimpulkan bahwa ada pengaruh yang besar melalui metode bercerita terhadap kemampuan menyimak anak (Rahmat dan Mamoto, 2016, p. 63). Sedangkan menurut Doludea, dalam penelitiannya menyimpulkan bahwa siklus metode bercerita dengan wayang kertas memberikan peningkatan kemampuan menyimak anak (Doludea dan Nuraeni, 2018, p. 1-5).

Berdasarkan latar belakang inilah peneliti tertarik untuk melakukan penelitian mengenai kemampuan menyimak pada anak dalam kegiatan bercerita.

Adapun permasalahan dalam penelitian ini dirumuskan sebagai berikut:

1. Mengevaluasi bagaimana pelaksanaan kegiatan bercerita untuk menstimulasi kemampuan menyimak anak pada Taman Penitipan Anak (TPA) Athirah Makassar. Pelaksanaan kegiatan bercerita meliputi:

a. Cara pemilihan cerita dan isi cerita.

b. Cara penyajian cerita.

2. Mendeskripsikan bagaimana kemampuan menyimak anak dalam kegiatan bercerita pada Taman Penitipan Anak (TPA) Athirah Makassar. Kemampuan menyimak anak yang akan diteliti antara lain:

a. Mengetahui judul dan tokoh dalam cerita.

b. Memahami isi cerita.

c. Menceritakan kembali cerita dengan bahasa sendiri.

3. Mengidentifikasi faktor pendukung dan penghambat kemampuan menyimak anak dalam kegiatan bercerita. 


\section{METODE}

\section{Jenis dan Lokasi Penelitian}

Salah satu metode penelitian yang saat ini cukup banyak digunakan dibidang pendidikan adalah kajian kualitatif. Metode penelitian kualitatif adalah suatu penelitian yang dtujukan untuk mendeskripsikan dan menganalisis fenomena, peristiwa, aktivitas sosial, sikap, kepercayaan, persepsi, pemikiran orang secara individu maupun kelompok. Beberapa deskripsi digunakan untuk menemukan prinsip-prinsip dan penjelasan yang mengarah pada penarikan kesimpulan (Bachri, 2010, 46-62).

Berdasarkan tujuan penelitian ini, yaitu kemampuan menyimak anak melalui kegiatan bercerita, maka data yang diperlukan bersifat deskriptif, yaitu dalam bentuk kata-kata, uraian-uraian dan juga dapat berupa angka-angka disertai penjelasan. Bogdan dan Taylor sebagaimana dikutip Moleong, menyatakan bahwa penelitian kualitatif merupakan prosedur penelitian yang menghasilkan data deskriptif berupa kata-kata tertulis atau lisan dari orang-orang dan perilaku yang dapat diamati (Nafis, 2013, p. 48). Penelitian ini dilaksanakan pada Taman Penitipan Anak (TPA) Athirah Makassar.

\section{Teknik dan Instrumen Pengumpulan Data}

\section{Observasi/Pengamatan}

Glesne dan Peshkin percaya bahwa pengamatan yang melibatkan peneliti secara langsung adalah sangat tepat dalam pengumpulan yang secara teliti (Glesne \& Peshkin, 1992). Posisi participant observer sebagaimana yang disarankan oleh PurcellGates, menyediakan suatu cara yang objektif untuk mengumpulkan informasi secara natural dalam suasana di dalam kelas (Purcell-Gates, 2004). Glesne \& Peshkin, menyatakan bahwa peranan participant observer memungkinkan untuk mengamati keadaan penelitian, tindakan, kejadian, dan gerak isyarat yang terjadi pada objek yang diamati (Glesne \& Peshkin, 1992). Pengamatan dalam penelitian ini dilakukan dalam kelas.

\section{Wawancara}

Melalui wawancara maka peneliti akan mengetahui hal-hal yang lebih mendetail tentang partisipan dalam menginterpretasikan situasi atau fenomena yang terjadi, dimana hal ini tidak bisa dilakukan melalui observasi (Susan Stainback, 1988 dalam Sugiyono, 2005).

\section{Teknik Analisis Data}

Mengacu pada teknik analisis data Miles dan Huberman, langkah-langkah menganalisis data adalah sebagai berikut (Sugiyono, 2014). Pertama, Kondensasi Data 
(pengembunan data). Memilih, pemusatan perhatian, penyederhanaan dan transformasi data kasar yang muncul dari catatan lapangan. Hal penting difokuskan serta diberi susunan yang sistematis sehingga akan lebih memudahkan. Data yang direduksi adalah data hasil observasi dan wawancara yang tidak mendukung tema yang dikaji. Kedua, Display Data. Display data adalah penyajian data atau informasi berdasarkan apa yang dapat dilihat dan apa yang diperoleh selama dalam observasi, baik itu dalam bentuk skema maupun tabel yang bertujuan agar data yang diperoleh menggambarkan keseluruhan sehingga memudahkan untuk penarikan kesimpulan. Ketiga, Interpretasi Data. Interpretasi data adalah mengkaji, menelaah dan menilai data yang berhubungan dengan fokus penelitian. Data yang telah diperoleh dihubungkan dengan hasil-hasil penemuan yang telah ada sebelumnya. Keempat, Penarikan Kesimpulan.

\section{HASIL DAN PEMBAHASAN}

\section{Pelaksanaan Kegiatan Bercerita pada TPA Athirah Makassar}

\section{Pemilihan Cerita dan Isi Cerita yang Disampaikan}

Berdasarkan hasil pengamatan bahwa dalam pemilihan cerita, tutor RR lebih cenderung memberikan kebebasan kepada anak dalam memilih cerita dengan membacakan buku cerita, meminta anak bercerita dengan gambar yang dibuatnya, bercerita sambil menggambar. Meskipun kadang-kadang tutor RR menentukan sendiri cerita tanpa melibatkan anak. Sedangkan tutor WA lebih cenderung menentukan sendiri jenis cerita yang disampaikan kepada anak. keputusan untuk tidak melibatkan anak dalam pemilihan cerita bagi tutor RR maupun WA disebabkan karena keterbatasan waktu pembelajaran dan sarana dan prasarana penunjang kegiatan bercerita.

\section{Cara Penyajian Cerita}

Secara Teori, cara penyajian cerita dapat menjadi motivasi dalam mengembangkan daya kesadaran dan memperluas imajinasi anak yang bertujuan untuk memperkaya dan mengembangkan wawasan yang dimiliki anak sehingga menjadi sebuah perilaku insani, dimana anak dapat mempertimbangkan baik dan buruknya tindakan yang dilakukan (Nurhayani, 2017, p. 54-59).

Menurut Nurhayani, metode bercerita memiliki indikator sebagai berikut: (a) penerapan konsep metode bercerita; (b) Menyebutkan unsur-unsur yang terdapat di dalam cerita (seperti menyebutkan tokoh dan watak tokoh yang terdapat di dalam cerita); (c) Mengungkapkan pikiran-pikiran melalui bahasa lisan; seperti menirukan suara atau kata dan bunyi bahasa serta menemukan kata-kata yang baru (Nurhayani, 2017, p. 57). Jadi berdasarkan indikator tersebut peneliti mencoba mengamati obyek penelitian dan kemudian memberikan kesimpulan. 
Dalam penyajian cerita, peneliti mengamati kedua tutor yang menggunakan cara yang berbeda dalam bercerita, terutama terluat dari pemilihan media yang digunakan. Tutor pertama bercerita tanpa menggunakan alat peraga. Berdasarkan hasil pengamatan bahwa kegiatan bercerita yang dilakukan oleh tutor tanpa menggunakan alat peraga cukup memadai dalam hal cara penyajian cerita. Tutor menggunakan intonasi suara, mampu menirukan suara kucing dan tikus yang sedang berkelahi. Anak-anak yang mendengarkan cerita ikut menirukan suara tutor dan berperan sebagai tokoh dalam cerita. Ketika tutor menyanyikan lagu, anak-anak ikut bernyanyi, bahkan beberapa diantara mereka terlihat berdiri sambil bergoyanggoyang. Kadang-kadang tutor meninggikan ataupun menurunkan intonasi suara untuk menarik perhatian anak. Tutor menguasai keterampilan dalam bercerita sehingga anak terlihat menikmati cerita yang diperdengarkan kepada mereka (Data observasi).

Dalam bercerita tutor pertama juga menggunakan media audiovisual berupa televisi dan VCD untuk memutarkan cerita kepada anak, sebagai salah satu variasi bercerita. Cara ini ditempuh untuk mengatasi kejenuhan anak. Kegiatan membacakan cerita adalah kegiatan bercerita menggunakan buku cerita. Dalam kegiatan ini tutor membacakan cerita sebuah buku kepada anak. Kegiatan ini dalam rangka mengembangkan kemampuan mendengar anak, karena biasanya anak senang akan cerita yang dibacakan oleh orang dewasa walaupun ada kata-kata yang belum dipahami anak (data wawancara) Tutor menjelaskannya dengan intonasi suara dan gambar yang terdapat di dalam buku dapat membantu menjelaskan isi cerita yang dibacakan.

Tutor kedua menggunakan boneka tangan. Alat peraga ini digunakan sebagai pelengkap, misalnya sebagai pembuka cerita dapat juga sebagai tokoh cerita secara utuh mirip cerita di panggung boneka. Boneka juga cocok sebagai media untuk memperkenalkan bintang tamu, memberikan pengumuman atau menenangkan suasana.

Dalam bercerita kedua tutor menggunakan pendekatan Contextual Teaching Learning $(\mathrm{CTL})$, suatu pendekatan yang menekankan pada proses keterlibatan siswa secara penuh untuk menemukan materi yang dipelajari dan menghubungkannya dengan situasi kehidupan nyata sehingga mendorong siswa untuk dapat menerapkannya dalam kehidupan mereka. Cerita yang dipilih adalah cerita yang sarat dengan nilai-nilai yang berhubungan dengan kehidupan anak. Cerita yang mengajarkan tentang bagaimana berbuat baik kepada orang. Misalnya dengan mengucapkan terima kasih kepada teman yang telah meminjamkan pensil sehingga anak dapat menghubungkan konsep tentang terima kasih dalam konteks yang lain dan pada akhirnya pesan-pesan yang disampaikan dalam cerita dapat diterapkan dalam kehidupan mereka sehari-hari.

Materi yang disampaikan dalam cerita tidak dimaksudkan untuk menggurui anak atau menanamkan tentang suatu konsep secara pasif kepada anak. Menurut Sanjaya, pendekatan CTL menekankan kepada proses keterlibatan siswa untuk 
menemukan materi, artinya proses belajar diorientasikan pada proses pengalaman secara langsung (Sanjaya, 2006 dalam Nur, 2014, p. 16). Hal ini sangat sesuai dengan pelaksanaan kegiatan bercerita dengan menggunakan alat peraga dimana anak dapat terlibat didalamnya dan memiliki pengalaman berinteraksi dengan alat peraga secara langsung. Menghadirkan berbagai macam benda-benda dari alam untuk memperkenalkan ciptaan Tuhan dalam kegiatan bercerita dapat memberikan pengalaman langsung kepada anak. Proses belajar dalam konteks CTL tidak mengharapkan agar siswa hanya menerima pelajaran, akan tetapi proses mencari dan menemukan sendiri materi pelajaran.

Penggunaan alat peraga memberikan kontribusi yang besar terhadap ketertarikan anak dan kemampuan menyimaknya (Dhieni, 2007). Penggunaan alat peraga dalam kegiatan berceritabukan merupakan fungsi tambahan tetapi mempunyai fungsi tersendiri sebagai alat bantu untuk mewujudkan situasi belajar yang efektif. Alat peraga digunakan untuk melengkapi proses belajar supaya lebih menarik perhatian siswa (Sudjana, 2008).

Dari beberapa hasil penelitian yang dilakukan oleh para ahli bahwa anak belajar sebesar 20 persen dari apa yang didengar, 50 persen dari apa yang didengar dan dilihat, 70 persen dari apa yang didengar, dilihat dan didiskusikan, dan 90 persen dari apa yang didengar, dilihat, didiskusikan dan dilakukan (Farida Tizen, 2008).

Sesuai dengan pendapat Bruner berkenaan dengan perkembangan pikiran anak yang dikaitkan dengan perkembangan bahasa anak bahwa anak memahami dunia sekitarnya dengan tiga tingkatan Modus Perwakilan Pemikiran yaitu tiga cara pemikiran yang menggambarkan (dalam arti memahami) pengertian tentang objekobjek yang di amati di dunia sekitar (Tampubolon, 1991). Ketiga tingkatan Modus Perwakilan Pemikiran tersebut yaitu:

1. Modus Enaktif yaitu cara pikiran anak bekerja pada taraf ini adalah melalui gerakan-gerakan yang dilakukannya secara aktif. Dia mengenali dan memahami dunia sekitarnya melalui gerakan-gerakannya. Dalam persepsinya objek-objek di sekitarnya masih seperti himpunan acak yang tak berbeda-beda. Gerakangerakan objek selalu mendapat perhatiannya.

2. Modus Ikonis yaitu pikiran anak bekerja membentuk gambaran atau citra dari objek-objek yang diamatinya. Kemampuan membentuk citra dalam pikiran adalah permulaan berkembangnya pikiran bernalar pada anak, karena dengan citra itu anak dapat memahami perbedaan serta hubungan antara objek-objek.

3. Modus Simbolis yaitu dalam masa perkembangan ini, anak telah dapat menggunakan symbol-simbol terutama bahasa dalam berpikir. Dia tidak lagi terikat pada objek-objek konkret atau kehadiran objek-objek itu. Dia telah mampu berpikir abstrak, logis dan bernalar dengan alat bahasa. Untuk modus ketiga ini dapat dikembangkan dengan bercerita tanpa alat peraga. 


\section{Kemampuan Menyimak Anak dalam Kegiatan Bercerita pada Taman Penitipan Anak Athirah}

Perkembangan keterampilan menyimak pada anak berkaitan dengan keterampilan berbahasa khususnya berbicara. Anak yang berkembang keterampilan menyimaknya, akan berpengaruh terhadap perkembangan keterampilan berbicaranya. Kedua keterampilan berbahasa tersebut merupakan kegiatan komunikasi dua arah yang bersifat langsung dan dapat merupakan komunikasi yang bersifat tatap muka (Dhieni, 2007).

Keterampilan menyimak merupakan bagian yang penting dan tidak dapat diabaikan dalam pengajaran bahasa, terutama bila tujuan penyelenggaraannya adalah penguasaan kemampuan berbahasa selengkapnya (Sari, 2016, p. 1). Dalam pengajaran bahasa semacam itu, perkembangan dan tingkat penguasaan kemampuan menyimak perlu dipantau dan diukur melalui penyelenggaraan penilaian kegiatan menyimak.

Kemampuan menyimak anak akan lebih baik jika dalam pelaksanaan kegiatan bercerita menggunakan alat peraga dibanding bercerita tanpa alat peraga. Anak dapat menyebutkan dan mengenal semua tokoh dalam buku cerita, cerita yang diputarkan melalui televisi, cerita dengan menggunakan gambar maupun cerita dengan boneka tangan. Mereka dapat mengingat warna baju, peran yang dimainkan oleh seorang tokoh. Anak juga memiliki kemampuan yang sama jika dipertontonkan cerita melalui televisi. Mereka dengan mudah menghafal apa yang diungkapkan oleh tokoh idola mereka, menirukan gerakannya bahkan menghafal sebagian dari nyanyian pengiring cerita. Sangat berbeda jika kegiatan bercerita dilakukan tanpa menggunakan alat peraga. Anak dapat mengenal tokoh, ungkapan tokoh dan karakter tokoh tidak seluruhnya. Ketiga orang anak yang menjadi fokus penelitian akan tertarik mendengarkan cerita jika menggunakan alat peraga dan cerita tersebut berhubungan dengan pengalaman atau kehidupan sehari-hari anak. Kesemuanya tergantung kepada bagaimana tutor mampu menarik perhatian anak dan memotivasi anak untuk mendengarkan cerita dengan baik. Dalam proses menyimak, seseorang tidak memusatkan perhatian pada setiap kata yang didengarnya melainkan inti pesan yang terdengar. Misalnya sewaktu kita menyimak acara di radio, kita hanya menangkap beberapa hal dan tidak dapat menangkap beberapa hal yang lain. Tidak tertangkapkan beberapa hal itu disebabkan oleh kurang perhatian, kurang tertarik pada topik, atau kurang efisien dalam menyimak (Rahmina, 2007).

Kemampuan memusatkan perhatian sangat penting dalam menyimak, baik sebelum, sedang maupun setelah proses menyimak berlangsung. Artinya kemampuan memusatkan perhatian selalu diperlukan dalam setiap fase menyimak. Memusatkan perhatian terhadap sesuatu berarti yang bersangkutan memusatkan pikiran dan perasaannya pada objek itu.

Disamping kemampuan memusatkan perhatian, masih ada satu kemampuan lagi yang diperlukan dalam kegiatan menyimak, yakni kemampuan mengingat. (Rahmina, 2007) Pada saat menyimak berlangsung, kemampuan menyimak 
digunakan untuk mengingat bunyi yang sudah didengar, perangkat kebahasaan untuk mengidentifikasi dan menafsirkan makna bunyi bahasa. Anak yang menyimak cerita dengan baik akan mampu mengingat bunyi yang didengar, isi dari bahan simakan.

Pesan yang sudah ditangkap, ditafsirkan dan dipahami maknanya. Setelah itu makna pesan itu perlu pula ditelaah, dikaji, diuji kebenaran isinya. Di sini diperlukan pengalaman yang luas, kedalaman dan keluasan ilmu dari penyimak. Kemampuan ini terlihat dari masing-masing responden yang dapat memahami isi cerita dengan baik meskipun dengan pendapat yang berbeda-beda. Hal ini disebabkan karena perbedaan pengalaman dan pengetahuan responden (Dhieni, 2007).

Dari hasil pengamatan terlihat bahwa ketiga responden melakukan kegiatan menyimak apresiatif yaitu penyimak (anak) larut dalam bahan yang disimaknya. Responden terpaku dalam menikmati dramatisasi cerita. Secara imajinatif penyimak seolah-olah ikut mengalami, merasakan, melakukan karakter pelaku cerita yang dilisankan. Tanpa disadari ketiga responden juga telah menyimak dengan tujuan untuk mengkomunikasikan ide dan perasaan. Anak sebagai penyimak memahami, merasakan ide, gagasan, perasaan tutor yang membawakan sehingga terjadi sambung rasa antara pembicara dengan pendengar.

\section{Faktor Pendukung dan Penghambat Kemampuan Menyimak Anak dalam Kegiatan Bercerita pada Taman Penitipan Anak Athirah}

Berdasarkan hasil penelitian selama dalam proses pengumpulan data terlihat bahwa faktor pendukung maupun penghambat kemampuan menyimak pada anak dalam kegiatan bercerita bergantung kepada sejumlah faktor. Faktor-faktor tersebut antara lain:

\section{Faktor Pembawa Cerita (Tutor)}

Pembicara dalam hal ini adalah tutor yang menyampaikan pesan, ide, informasi melalui cerita kepada para anak didik melalui bahasa lisan. Kualitas tutor sebagai pembawa cerita, keahliannya dalam bercerita termasuk didalamnya penguasaan keterampilan bercerita, dan karismanya sangat berpengaruh terhadap anak sebagai pendengarnya.

Penggunaan bahasa yang baik dan benar merupakan faktor pendukung proses menyimak anak. Tutor menyampaikan cerita dalam bahasa yang baik dan benar. Ucapan jelas, intonasi tepat, susunan kalimat sederhana dan benar, pilihan kata atau istilah tepat.

Selain itu penggunaan ekspresi wajah dan gerakan tubuh juga memegang peranan yang penting terhadap kemampuan menyimak anak. Tutor yang tampil dengan gaya yang menarik dan simpatik akan menarik pehatian anak. Tutor harus menghindari tingkah laku yang dibuat-buat atau berlebih-lebihan. Beberapa hasil pengamatan memperlihatkan bahwa penggunaan bahasa tubuh, mimik dan ekspresi wajah dapat menarik perhatian anak. 
Majid menyatakan bahwa anak ketika menyimak cerita guru diupayakan agar bisa merasakan dengan perasaan mereka berbagai kondisi yang ada dalam cerita seperti sedih, senang dan marah. Apalagi bila dalam penyampaiannya sang guru dapat mengolah kondisi-kondisi itu dengan baik dalam penyampaiannya (Majid, 2015).

Pemberian motivasi berupa pujian dan hadiah (memberikan permen) kepada anak yang berhasil menjawab pertanyaan yang berkaitan dengan isi cerita secara baik dan benar akan mendorong anak untuk memperhatikan jalannya cerita dengan baik. Sebagaimana disebutkan oleh Majid bahwa ketertarikan anak untuk mendengar cerita biasanya bersifat paksaan. Motivatornya adalah bagaimana cara guru menyampaikan cerita dan berapresiasi terhadap anak (Majid, 2015).

\section{Faktor Cerita}

Cerita merupakan isi, pesan, atau informasi yang hendak disampaikan oleh seseorang pembicara (tutor) kepada pendengarnya (anak). Cerita yang dibawakan haruslah cerita yang menarik, diminati dan disenangi oleh anak (Rahmina, 2007). Cerita berkaitan dengan kehidupan sehari-hari anak, sehingga anak tidak bingung dengan apa yang didengarnya karena sudah terbiasa dalam kehidupannya.

\section{Faktor Penyimak (Anak)}

Penyimak adalah anak yang mendengarkan dan memahami isi bahan simakan (cerita) yang disampaikan oleh pembicara dalam suatu peristiwa menyimak. Dibandingkan dengan faktor pembicara (pembawa cerita), pembicaraan (cerita) dan situasi, faktor penyimak adalah yang terpenting dan paling menentukan keefektifan dalam peristiwa menyimak (Rahmina, 2007). Sebab, walau ketiga faktor yang tersebut sudah memenuhi segala persyaratan, bila si penyimak tidak mau menyimak maka siasialah semuanya. Sebaliknya biarpun faktor pembawa cerita, cerita, dan situasi kurang memadai, kurang sempurna, asal si penyimak (anak) berusaha sungguh-sungguh, tekun, dan kerja keras maka keefektifan menyimak dapat tercapai. Anak akan tertarik mendengarkan cerita jika cerita yang diperdengarkan kepada mereka adalah cerita yang sesuai dengan pengalaman dan kehidupan mereka sehari-hari.

Faktor penyimak berkaitan erat dengan tujuan, tingkat pemahaman, pengalaman dan strategi anak dalam memonitor pemahaman mereka terhadap informasi yang disampaikan. Anak yang tidak memiliki motivasi atau alasan yang kuat untuk menyimak informasi seringkali mengalami masalah dalam memahami informasi tersebut.

\section{Faktor Situasi Belajar}

Situasi dalam menyimak diartikan segala sesuatu yang menyertai peristiwa menyimak di luar pembawa cerita, pembicaraan (cerita), dan menyimak. Situasi tersebut sangatlah berpengaruh dan menentukan keefektifan menyimak (Rahmina, 
2007). Lingkungan yang kondusif bagi anak untuk menyimak adalah lingkungan yang bebas dari berbagai gangguan termasuk suara atau bunyi-bunyian. Dengan situasi ruangan yang tenang anak dapat memusatkan perhatiannya pada informasi yang diberikan (Dhieni, 2007). Ruangan atau tempat berlangsungnya peristiwa menyimak harus menunjang. Ruangan yang menunjang adalah ruangan yang memenuhi persyaratan ventilasi, penerangan, penataan tempat duduk pendengar, posisi duduk pembawa cerita, warna ruangan dan luas ruangan.

Menurut Sudjana, penggunaan alat peraga dalam kegiatan belajar seperti gambar, boneka, papan tulis, benda-benda tiruan, benda-benda asli, televisi bukan merupakan fungsi tambahan tetapi mempunyai fungsi tersendiri sebagai alat bantu untuk mewujudkan situasi belajar mengajar yang efektif. Penggunaannya dalam pengajaran bukan semata-mata alat hiburan, dalam arti digunakan hanya sekedar melengkapi proses belajar supaya lebih menarik perhatian siswa. Penggunaan alat peraga dalam pengajaran diutamakan untuk meningkatkan mutu belajar mengajar (Sudjana, 2008). Dengan perkataan lain menggunakan alat peraga, hasil belajar yang akan dicapai akan diingat siswa dalam jangka waktu yang lebih lama, sehingga pelajaran akan mempunyai nilai tinggi.

Peristiwa menyimak yang berlangsung dalam ruangan yang baik, waktu yang tepat, suasana tentram, nyaman, dan menyenangkan serta dilengkapi dengan peralatan yang fungsional dapat diharapkan hasilnya yang efektif.

\section{KESIMPULAN}

\section{Kesimpulan}

Berdasarkan hasil penelitian dapat disimpulkan bahwa: (1) Dalam peaksanaan kegiatan bercerita, tutor memilih cerita yang mengandung nilai-nilai moral yang mengarah pada pengembangan emosional, sosial dan spiritual anak yang dikembangkan dalam program pembentukan perilaku anak. Penyajian cerita dilaksanakan oleh dua orang tutor dengan cara mereka masing-masing; (2) Kemampuan menyimak anak dalam kegiatan bercerita pada Taman Penitipan Anak Athirah dapat diamati melalui kemampuan anak mengetahu judul dan tokoh dalam cerita, memahami isi cerita dan meceritakan kembali cerita dengan bahasa sendiri. (3) Faktor pendukung kemampuan menyimak anak dalam kegiatan bercerita adalah Faktor pembawa cerita (tutor), faktor cerita, faktor penyimak (anak) dan faktor situasi belajar.

\section{Saran}

Berdasarkan kesimpulan tersebut, dikemukakan beberapa saran sebagai berikut: (1) Pelaksanaan kegiatan bercerita hendaknya dilaksanakan pada waktu yang tepat, dimana kondisi anak masih segar untuk mendengarkan cerita; (2) Cerita yang diperdengarkan kepada anak belum mengembangkan kemampuan imajinasi dan kreativitas anak secara optimal. Dalam bercerita pengembangan imajinasi dan 
kreativitas anak hendaknya diperhatikan; (3) Lama waktu yang digunakan untuk bercerita hendaknya tidak lebih dari 15 menit dengan cerita yang tidak terlalu panjang agar anak tidak bosan mendengarkan cerita; (4) Dalam kegiatan bercerita hendaknya anak dilibatkan dalam memilih cerita, memberi kesempatan yang sama kepada setiap anak untuk menjawab pertanyaan yang berhubungan dengan cerita dan menceritakan kembali cerita dengan bahasa mereka sendiri sehingga kemampuan menyimak cerita setiap anak dapat diketahui.

\section{KEPUSTAKAAN}

Bachri, Bachtiar S. (2010). Meyakinkan Validitas Data Melalui Triangulasi Pada Penelitian Kualitatif. Jurnal Teknologi Pendidikan, 10(1), 46-62.

Dariyo, Agus. (2010). Psikologi Perkembangan Anak Tiga Tahun Pertama. Bandung: PT. Refika Aditama.

Dhieni Nurbiana, dkk. (2007). Pokok Metode Pengembangan Bahasa. Jakarta: Universitas Terbuka.

Direktorat Tenaga Teknis (Diktentis). (2003). Pertumbuhan dan Perkembangan Anak Usia 0-6 tahun. Jakarta: Ditjen PLSP Departemen Pendidikan Nasional.

Doludea, Anny, dan Lenny Nuraeni. (Januari 2018). Meningkatkan Keterampilan Menyimak Pada Anak Usia Dini 5-6 Tahun Dengan Metode Bercerita Melalui Wayang Kertas Di TK Makedonia. CERIA (Cerdas Energik Responsif Inovatif Adaptif), 1(1), 1-5.

Glesne, C., \& A. Peshkin. (1992). Becoming Qualitative Researchers: An Introduction. White Plains, NY: Longman Publishing Group.

Majid, Abdul Azis. (2015). Mendidik Anak Lewat Cerita. Jakarta: Mustaqiim.

Nafis, Ismi Ulin. (2013). Pelaksanaan Pembelajaran Agama Islam Bagi Penyandang Tuna Netra Di Balai Rehabilitasi Sosial Distrarastra Pemalang II. Skripsi, IAIN Walisongo. http://eprints.walisongo.ac.id/1587/3/083111071_Bab3.pdf.

Noviana, Lia. (Januari 2013). Pengaruh Metode Bercerita Terhadap Kemampuan Menyimak Pada Anak Kelompok Bermain Tunas Bangsa Di Ds.Wotansari, Kec.Balongpanggang, Kab. Gresik. PAUD Teratai, 2(1). Diakses 11 Juni 2020. https://jurnalmahasiswa.unesa.ac.id/index.php/paud-teratai/article/view/902.

Nur, Faizah M. (2014). Penerapan Pendekatan Contextual Teaching And Learning (CTL) Untuk Meningkatkan Hasil Belajar Siswa Pada Materi Struktur Dan Fungsi Bagian Tumbuhan Di Kelas IV SD Negeri 2 Muara. JUPENDAS, 1(2), 15-21. https://media.neliti.com/media/publications/71198-ID-none.pdf.

Nurbiana, Dhieni, dkk. (2015). Metode Pengembangan Bahasa. Jakarta: Universitas Terbuka.

Nurhayani, Isma. (Februari 2017). Pengaruh Penggunaan Metode Bercerita Terhadap Kemampuan Menyimak Siswa Pada Mata Pelajaran Bahasa Indonesia. Jurnal Pendidikan UNIGA, 4(1): 54-59. 
Priyanto, Aris. (2014). Pengembangan Kreativitas Pada Anak Usia Dini Melalui Aktivitas Bermain. Jurnal Ilmiah Guru "COPE", (2): 41-47.

https://journal.uny.ac.id/index.php/cope/article/viewFile/2913/2434.

Purcell-Gates, V. (2004). Ethnographic Research. Literacy Research Methodologies, $92-$

113. New York: Guilford Publications.

Rahmat, Abdul, and Ertiwi Mamonto. (Juni 2016). Pengaruh Metode Bercerita

Terhadap Kemampuan Menyimak Di Kota Selatan Gorontalo. Journal of

Nonformal Education and Community Empowerment, 5(1), 63-72. Diakses 11 Juni

2020. https://journal.unnes.ac.id/sju/index.php/jnfc/article/view/9728/6738.

Rahmina, Lim. (2007). Listening In Action: Upaya Meningkatkan Kemampuan Menyimak Pebelajar. Jurnal Fakultas Pendidikan Bahasa dan Sastra. Universitas Pendidikan Indonesia.

Rupina, Purwanti, Yuline. (2016). Peningkatan Kemampuan Menyimak Melalui Metode Bercerita Dengan Media Gambar. Portal Jurnal Ilmiah Universitas Tanjungpura, $5(1), 1-11$.

Sari, Wulan. (2016). Kemampuan Menyimak Wawancara Pada Siswa Kelas VII SMP

Negeri 1 Sekampung Tahun Ajaran 2014/2015. Skripsi, Fakultas Keguruan dan

Ilmu Pendidikan, Universitas Lampung.

http://digilib.unila.ac.id/21036/16/BAB\%20l.pdf.

Sudjana, Nana. (2008). Dasar-dasar Proses Belajar Mengajar. Bandung: Sinar Baru.

Sugiyono. (2005). Memahami Penelitian Kualitatif. Bandung: Alfabeta.

. (2014). Metode Penelitian Pendidikan Pendekatan Kuantitatif, Kualitatif, dan $R \& D$. Bandung: Alfabeta.

Syarifuddin, Syamsunur. (2010). Faktor-Faktor Yang Mempengaruhi Kemandirian

Toileting Pada Anak Umur 2 - 3 Tahun Di Wilayah Kerja Puskesmas Pangkajene

Kabupaten Sidrap. Skripsi, Prodi Keperawatan, Fakultas Ilmu Kesehatan,

Universitas Islam Negeri Makassar.

Tampubolon. (1991). Mengembangkan Minat dan Kebiasaan Membaca pada Anak.

Bandung: Angkasa.

Tizen, Ella Farida. (2008). Media Gambar. Bandung: Nujahid Press. 